\title{
JE SUIS EN TRANSIT (Adventures in Google Translate)
}
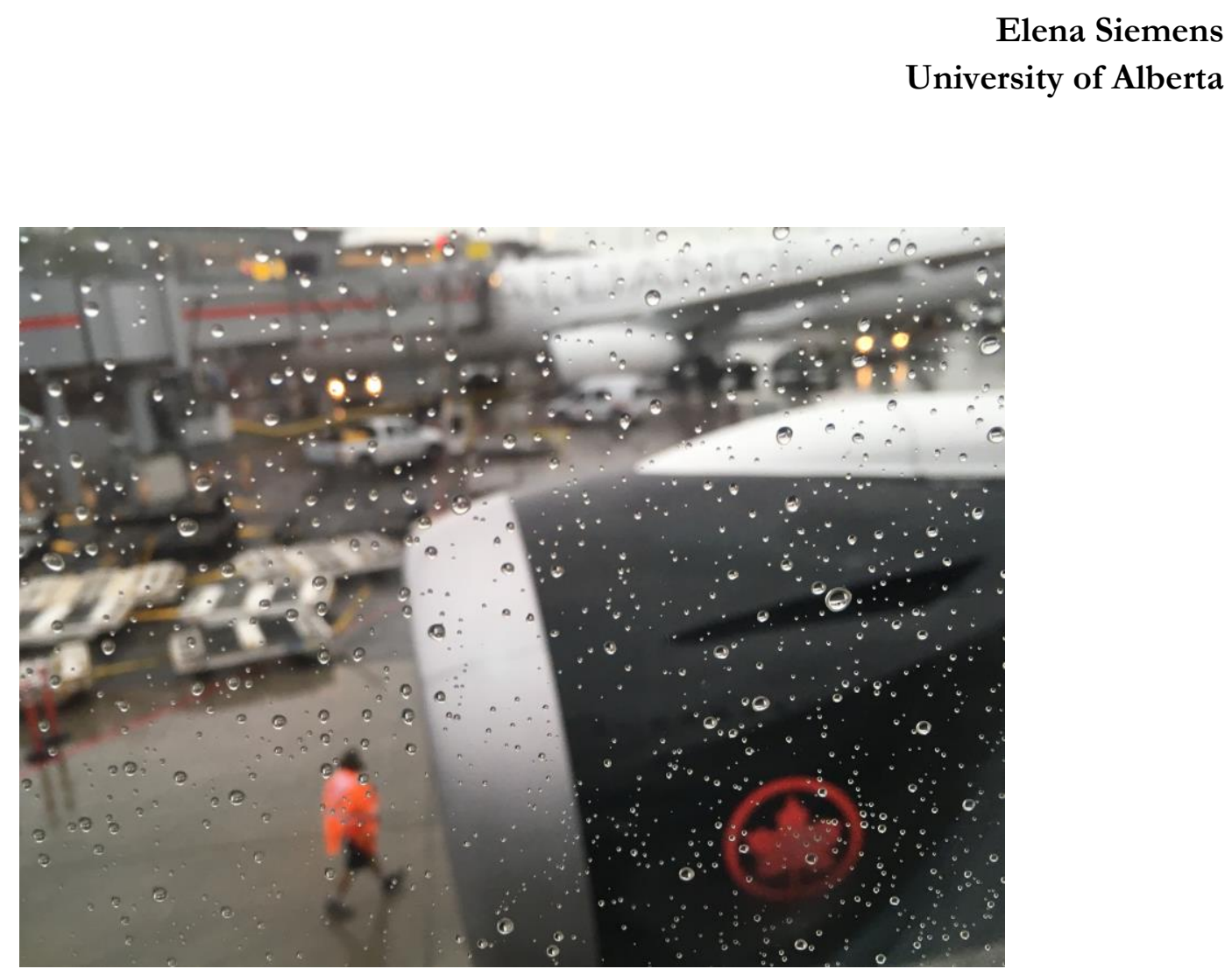

Photo Elena Siemens

Je suis en transit a Montréal, mon prochain vol a l'étranger est demain matin. Londres d'abord, puis Moscou, trois semaines au total. Je ne te reverrai pas encoure. Combien de temps cela a-t-il duré? (I'm in transit in Montreal, my next flight overseas is tomorrow morning. First London, then Moscow, three weeks in total. I won't see you yet again. How long has it been?)

I'm staying on Sherbrook, a nice room, but it isn't anything like the landmark Queen Elizabeth Hotel, before its renovation, when it still felt like history and the old world, and Lennon and Yoko Ono. C'est la que nous nous rencontrés en décembre de quelle année? (This was where we met in December of what year?). We had some take-outs and wine, and you took that remarkable snapshot of the long posh corridor leading from my room - on what floor? - to the elevator. 
My room faces clusters of high-rises of different vintages on Sherbrook and beyond. On Sherbrook we met at the café Humble Lion. Un lion peut-il etre humble? Cella ressemble a une contradiction en terms, mais ce n'est peut-etre pas le cas. (Can a lion be humble? Sounds like a contradiction in terms, but maybe it isn't). The place was packed, we sat by the door, and talked about the latest, whatever the latest was at that time. With some people it doesn't really matter what you talk about, you just want to see their face and hear them talk.

En dessous de Sherbrook se trouver la rue Sainte Catherine ou nous nous rencontrés un jour d'été d'une autre année. Tu es venu a bout de souffle, et la premiére chose que tu as dit était: Give us a fag! (Below Sherbooke is Saint Catherine Street, where we met on a summer day of another year. You arrived breathless, and the first thing you said was: Give us a fag!). And suddenly the world was painted red, and I was transported to London's Oxford Street, with its thick crowds, and people bumping into one another, and saying: Sorry, love.).

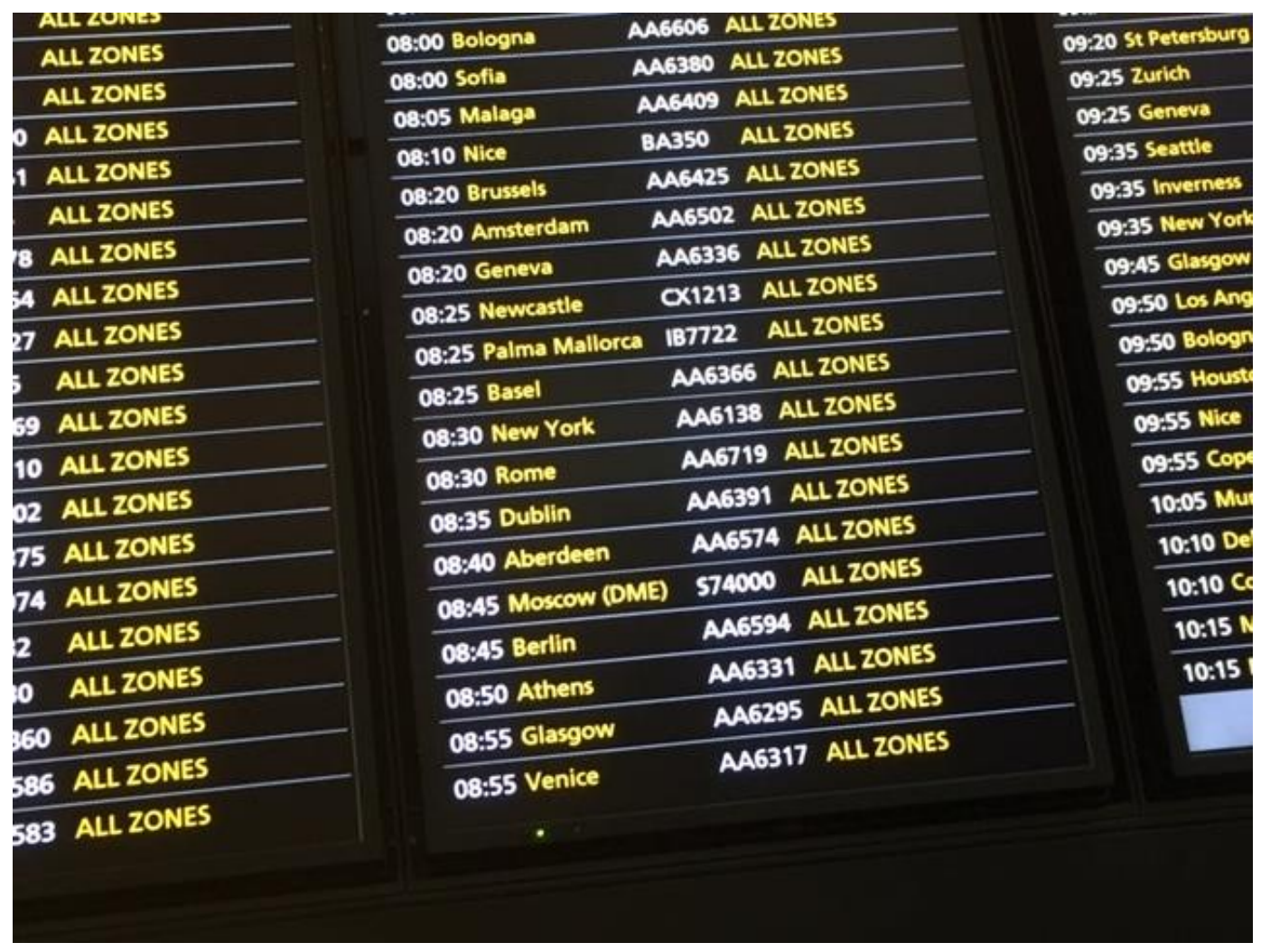

Photo Elena Siemens 
I'm in London for a few days before going to Moscow. As I learned later (too late!) from our email exchange, both of us were at the Tate Modern on more or less the same day. Une autre misconnection.

Subject: London, Tate Modern

You:

Wait, I was there a week ago, we went to the Tate Modern on Wednesday!! Why didn't you tell me you were there?!

I:

Picasso's Dancers and self at the Tate Modern a week ago. Now jet lagged and plotting my next escape.

В Москве из Домодедова на Павелецкую еду Аероэкспрессом. Без пробок, полчаса с небольшим, и ты в центре города. Большие окна, мягкие кресла, на спинке каждого реклама с зовущим в дорогу лозунгом. Например: Лето не расскажет маме! (In Moscow, I take the Aeroexpress train from Domodedovo Airport to Paveletsky station. No traffic jams. Just over a half hour, and you're in the city centre. The Aeroexpress has big windows, plush armchairs, each with an ad tempting you to take another journey. For example: Summer won't tell your mother!).

Аэроэкспресс - это промежуточное состояние. Ты уже не в самолете, но еще не в Москве. Можно строить радужные планы, потому что в этот момент совсем неважно, как там все будет на самом деле. Будет сказка с счастливым концом! (Riding the Aeroexpress places you in an in-between state. You are no longer on the plane, but not yet in Moscow. You can make bright rainbow-like plans, because at this moment it doesn't really matter at all how everything will really be there. There will be a fairytale with a happy ending!). 


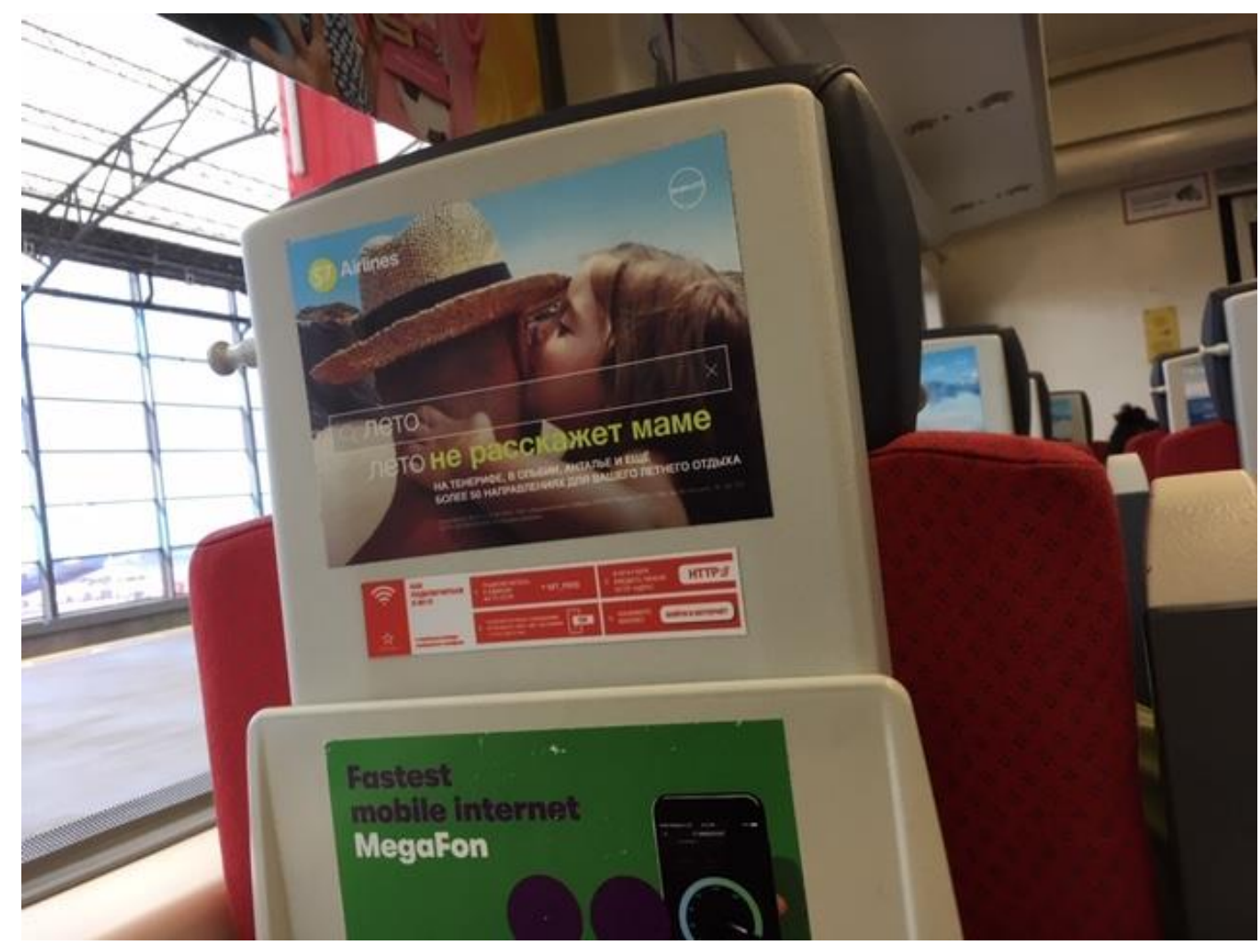

Photo Elena Siemens

Je suis de retour a Montréal pour un autre court séjour pour jeter quelques horaires sur mon décalage horaire avant de retourner plus a l'ouest. Tu es toujours a l'etranger. (I'm back in Montreal for another short stay to cast a couple of hours off my jetlag before heading back further West. You're still overseas). We're plotting another visit.

Продолжение следует. A souvre. To be continued.

Note on self-translation. For this project, I used Google Translate. It isn't a perfect tool, but its occasional grammar and vocabulary errors may help to capture the immediacy of writing. Google also delivers instant gratification. With digital translation you still maintain some control over your text, as long as you have a good command of at least one of the two languages. There are always some roadblocks. For example, Je suis en transit can be translated $Я$ в полете (literally: I'm in flight), denoting a similar but not an identical set of connotations. Each language has its own little secrets, and maybe it is a good thing. This way, everyone can choose what speaks to them the most. 